\title{
灰水利用的契机 \\ 对境外水域的探寻与思考 \\ WHEN THE ONLY WATER LEFT IS GRAY \\ - THE GROWING QUEST FOR FOREIGN WATERSHEDS
}

托马斯 · 尼德律斯特 景观设计师 (瑞士)

Thomas NIDEROEST Landscape Architect (Switzerland)

35 Line Street, Cambridge MA 02 I38, USA

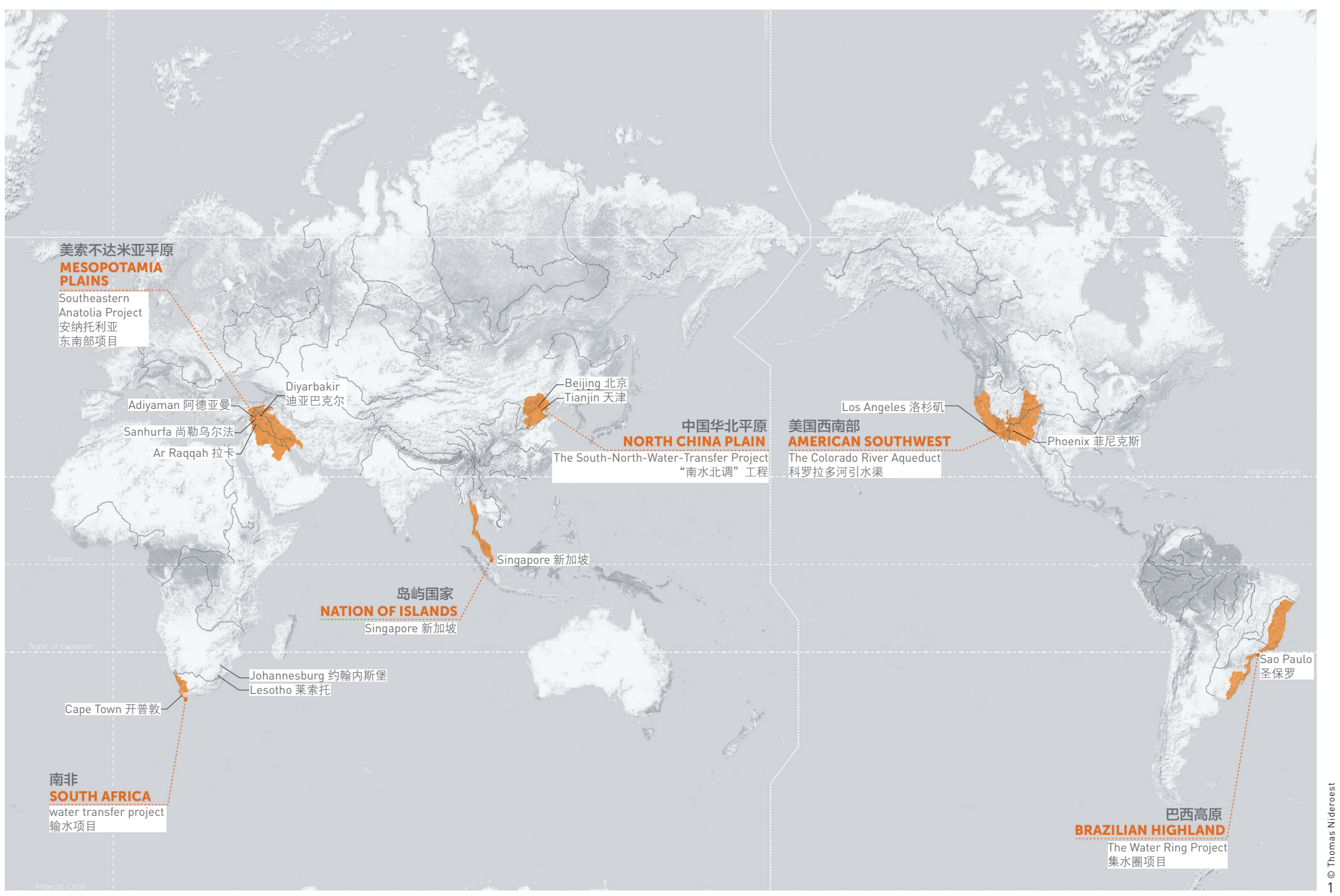




\section{1 关于干旱影响的国际调查}

2017年11月12日，南非《时报》报道 了有关开普敦市水资源紧缺的新闻, 同时表 明该市在替代水源的寻找上亦未取得实质性 进展 ${ }^{[1]}$ 。仅一个月后, 美国生命科学网发表 了一篇题为 《零水日: 开普敦或成为首个水 资源耗尽的大城市》的文章 ${ }^{[2]}$ 。极端气候所 带来的旱灾和缺水问题正侵袭着全球各地的 干旱地区，其中包括2010年发生在中国的 旱灾和沙尘暴、2011 2017年严重影响加 利福尼亚的前所未有的旱灾等。在经济迅猛 增长的背景下, 不断变化的环境与人口状况 之间相互作用，使国家或地区对可用水资源 的需求发生相应转变。干旱地区约占陆地 总面积的 $41 \%{ }^{[3]}$ ，承载着全球三分之一的人 口，更有多个特大城市坐落其中，以丰富的 矿产和肥沃的土壤创造了每年数十亿美元的 经济收 ${ }^{[3]}$ 。更大范围内气候系统的变化影 响着地区降水周期，二者又共同决定着水文 周期及水体情况, 补给着地区的淡水资源。 众所周知, 厄尔尼诺现象和拉尼娜现象 ${ }^{[4]}$ 均 会带来全球范围内的气温和降水的反常变 化。近年来因气候变化加剧所造成的降雨推 迟或转移 ${ }^{[4]}$, 影响了淡水的供应, 对自然和 人类发展造成了威胁。

“灰水利用的契机” 是由哈佛大学查 尔斯. 艾略特旅行奖学金资助的设计研究项 目。项目基于6个国际案例，对旱灾在干旱 地区的影响进行了调查 (图1)。通过记录 这些区域的水系统情况（图2），并结合对 相应流域所开展的大型项目的社会经济和社 会生态效应的分析, 该项调查揭示了全球普 遍存在的水资源短缺问题。下文将首先简要 介绍该项目中涉及的案例概况, 然后从景观 设计学层面探讨当前的水资源发展议题。该 项目意在透过设计研究的途径展示探究全球
问题的层面，将基于景观的规划和设计方法 视为构建多样化的地方干预措施的基础。

\section{2 超级工程和自然危机}

\section{1 罗斯福新政时期的 “资源稀缺” 模式}

迫于19世纪与20世纪之交的城市快速 发展, 洛杉矶市不得不从欧文斯流域引水 ${ }^{[5]}$ 。 颇具远见的洛杉矶水电管理局总工程师威 廉 - 穆赫兰提议建造首个洛杉矶引水渠 ${ }^{[6]}$ 。 为使项目获批, 穆赫兰以洛杉矶连年的干旱 问题为切入点（持续的干旱已造成了市民 的恐慌 ) ${ }^{[7]}$ 。他还预见到洛杉矶将迅速发展 为一个大都市, 因而将目光投向了科罗拉多 河。1922年, 《科罗拉多河契约》签订, 明 确了沿河7个相邻州的供水分配 ${ }^{[8]}$ —该协 定的出现恰逢其时，因为美国彼时即将再次 经历一场严重危机一-20世纪30年代，一 系列沙尘暴事件侵袭了美国中西部，加之经 济大萧条的影响, 胡佛大坝即在此背景下启 动 ${ }^{[9]}$ 。这项超级工程开辟了同类项目的新标 准, 并为加州引入了新的水源。此后, 利用 自然危机谋求经济发展成为了政府的一种应 对策略。在科罗拉多河被人为分为上下两段 进行管理后不久，加州成为首个提出水资源 供应诉求的州 ${ }^{[10]}$ 。为响应其诉求, $389 \mathrm{~km}$ 长的科罗拉多河引水渠、130km长的全美运 河及362km长的圣地亚哥引水渠等多个超级 工程开始建造。图3 7展现了科罗拉多河流 域水系统的景象, 大量水利工程的建设使位 于亚利桑那州葛兰峡谷大坝与毗邻墨西哥边 境的莫雷洛斯大坝之间的自然景观被不断边 缘化。

\section{2 全球水资源的商品化}

随着经济与人口的持续增长, 水资源 短缺地区亟需找到替代水源。为在维持当地 


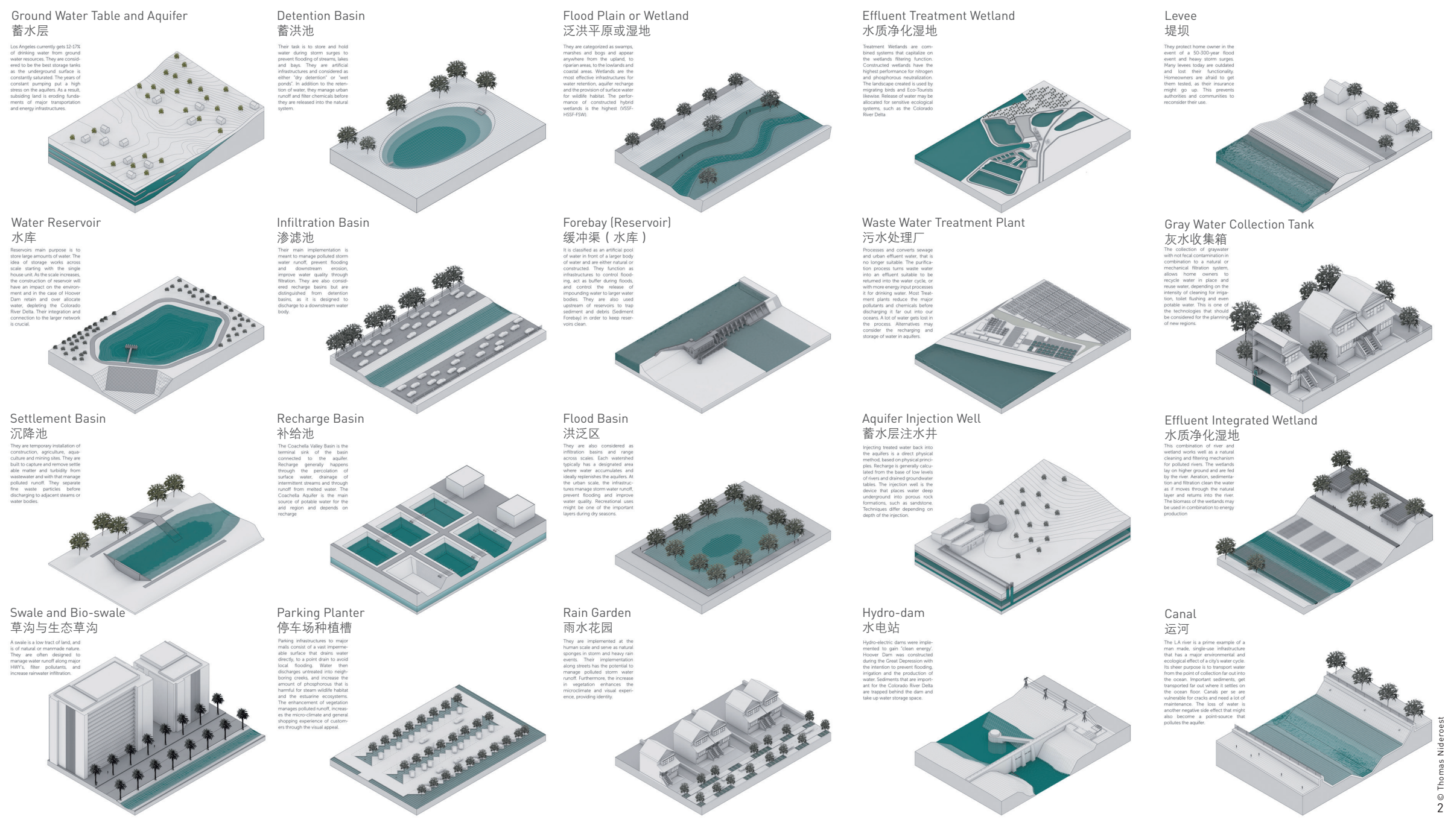

2. 洛杉矶市用于水资源储存 与运输的基础设施一览

2. Los Angeles water infrastructure catalogue between storage and conveyance
经济稳定发展的同时有效进行人口增长的预 测, 世界各地的政府开始借鉴加州的蓄水和 输水方法, 将水资源网络扩展到非本地流域 中。这种将水资源视作储备物资的意识 ${ }^{[11]}$, 使得资源利用超越管辖界限和国家边界。这 意味着来源于某个特定地域的水资源将被一 个或多个经济子系统加以利用 ${ }^{[11]}$ 。利用过的 或受污染的水体 (即灰水) 不再被视作“资 源” ，而是作为废水和污染物被排入污水 池 ${ }^{[12]}$ 。下面的三个案例将呈现这一城市化进 程所带来的多方面影响。

\subsection{1 中国华北平原一一南水北调工程}

北京地处中国华北平原，曾拥有丰富的 河流和淡水资源 ${ }^{[13]}$ 。华北平原是中国第二大
平原, 主要由黄河、淮河和海河冲积而成 ${ }^{[14]}$ 。 不断变化的降水周期、显著减少的降雨量、 严重的干旱、频发的洪水，以及迅速的经济 增长与城市扩张, 已严重超越了北京当地资 源的承受能力。地下水的过度汲取导致蓄水 层几近枯竭，工业排污管理不善造成水质下 降, 肥沃土地面临严重的沙漠化威胁 ${ }^{[13]}$ 。 1952年, 毛泽东主席提出通过向水资源丰 沛的南方借水, 以解决北方水资源短缺的 问题 ${ }^{[15]}$, 由此形成了建造超级水利基础设 施一包括2 $400 \mathrm{~km}$ 的运河及渠道网络的 南水北调工程的构想。该工程主要包括东 线、中线、西线三条调水线路。其通过连接 长江、淮河、海河和黄河, 形成了 “四横三 纵”的总体布局, 以调取长江流域的水资源
（图8～10 ） ${ }^{[13]}$ 。尽管面临环境短板，华北 平原仍在持续发展中。近期，中国中央政府 计划在北京和天津的南部建设百万级人口城 市一一雄安新区 ${ }^{[16]}$ 。尽管其建立可以缓解北 京的城市扩张所带来的影响 ${ }^{[16]}$, 但同时也 增加了北方地区整体用水需求。在这种背景 下, 对诸如南水北调这样 “以工程手段解决 生态难题” ${ }^{[17]}$ 的超级工程的构想应运而生。

\section{2 .2 南非一一零水日}

当前, 南非城市开普敦的水资源现状不 容乐观。曾有预测，2018年4月22日，开 普敦将面临 “零水日”危机 ${ }^{[18]}$ —导致这场 水资源浩劫的因素包括立法的不完善、机制 的不健全、议会中政治角色与技术角色的失 
调 ${ }^{[19]}$ 。气候变化的加剧引发了年降雨量的变 化, 而高温则造成水库水面蒸发量加大, 人 口向城市的不断聚集亦使问题更加严峻（图 11，12）。1998年, 《南非共和国水法》 颁布, 这是其后种族隔离时代所颁布的多项 法律的其中一部, 旨在保障公民的水资源供 给 ${ }^{[20]}$ 。该项法案对中央及地方的相关水资源 职责进行了划分: 中央政府需要履行其对水 资源的保护、开发、储存、管理和控制职 责 ${ }^{[18]}$; 省级和市级政府则负责当地水源的 管理、维护和运输 ${ }^{[19]}$ 。因此, 开普敦市级 政府事实上无权对该城市水供应基础设施进 行投资。此外, 与1998年新水法并行运作 的1968年《国家水资源指南》在诸多方面 已经过时, 其所列出的各项标准 (例如水质 规范) 不再适用于应对当前前所未有的水危 机。这一情况使当地的水管理更加复杂, 并 不可避免地阻碍了变革的进程。

\subsection{3 新加坡一一唯一且巨大的水资源挑战}

新加坡位于东南亚的热带岛屿之上, 于1963年脱离英国统治获得独立 ${ }^{[21]}$, 且自 1965年从马来西亚分离出来后, 依然维持 着其与马方原先签订的供水协议 ${ }^{[22]}$ 。但自马 来西亚经历了多次旱灾后, 从其南部城市柔 佛进口的水资源水质与水量开始下降 ${ }^{[22]}$ 。由 于新加坡与马来西亚两国的政治角力, 再加 上新马供水协议将在2061年终止, 新加坡 不得不改变其在水资源方面的政策方向 ${ }^{[23]}$ 。 为实现水资源独立, 新加坡第一任总理李光 耀将水资源相关事务列为政府政策和城市发 展的重中之重 ${ }^{[22]}$ 。

\section{3 景观，获取丰沛水源的途径?}

无论是对于社会发展还是包括农业与工 业在内的经济增长过程而言, 水资源都至关 重要。由于可用水资源的约束与限制对产品 的生产以及新工作岗位类型的出现有直接影 响, 因而成为了制约城市发展的重要因素。 前文提出, 罗斯福新政时期 “水之稀缺”的 论断伴随着水的商品化而产生。该供水方案 通过不断从境外流域获取水资源, 将水一能
网络从生产地扩展到消费地。由此, 中央集 控的供水系统不可避免地造成资源分配的地 域差异 ${ }^{[24]}$, 形成影响自然环境及其再生能力 的社会过程断层。尽管大型跨境引水项目能 够通过缓解水资源稀缺的情况维持经济子系 统的运行, 我们亦应提出如下问题: 倘若这 种中央集控的供水系统不断扩张, 一旦严重 干旱或其他重大灾难造成系统崩溃, 我们将 采取何种替代方案? 在这一背景下, 强调水 之可用量、质量以及对淡水资源的获取具有 增长极限的 “水峰值” 的概念 ${ }^{[25]}$, 或许能够 让我们重新审视通常被视作 “废水” 的灰水 的重要性。对“灰水”的关注能够将我们的 视野从“水之稀缺” 向 “水之充沛” 转变, 即从有赖于中央集控的跨流域调水策略, 转 向地方分控下依托于混合系统的灰水收集及 利用策略。

在中国, 为了应对华北平原地区的不 断发展, 亟需跨越辖区界限的规划和决策新 思维。如果能够发展出一套以景观过程为框 架的精明土地利用规范, 将能够更为充分地 利用城市和乡村的天然水体和湿地。例如,

“海绵城市建设”策略意在增强洪水期间的 城市弹性, 保护并提高溪流、湖泊和储水层 的水质, 增强市民与环境之间的社会 - 生态 联系。因此, 快速发展的中国城郊可被视为 一个净水收集及供给的巨大 “社区”。通过 回收和循环利用灰水, 该“社区” 使水循环 网络再度贯通, 充分发挥水作为“可再生资 源” 的优势。在南非, 西开普省的伯格河修
复工程通过废弃物和废水管理来解决水质问 题 ${ }^{[26]}$ 。沿伯格河而居的低收入群体能够从开 展的试点工程中获取更多有关水资源的知 识 ${ }^{[26]}$ 。这种互动形式也使得这一群体成为了 工程的主要受益者, 大大提升了人们自给自 足的能力和主人翁意识。新加坡在其淡水资 源极度匮乏的大背景下提出的四大 “国家水 喉” 计划 ${ }^{[27]}$, 使该国摇身变为水资源净产出 国。“国家水喉”计划的主要目的是在从马 来西亚进口淡水资源的基础上, 通过扩大蓄 水能力来集水。此外, 该计划通过与景观设 计项目紧密结合, 将市民和游客重新吸引至 自然景观之中。滨海堤坝 (图13) 以及碧山 宏茂桥公园便是该策略的典型案例。

上述案例及概念, 均是从本地出发应对 水资源短缺问题的尝试。这些基于景观的规 划和设计方法可以同时促进社会经济和社会 生态的发展。由此, 景观成为了一种超越其 自身学科价值的媒介, 为应对从大尺度地区 到小尺度社区所面临的关键性挑战提供了新 的范式与方法。如果这一观点能够得到充分 认识, 其将对城市发展产生积极影响。“灰 水利用的契机” 项目指出, 应对水资源短 缺问题不应局限于远程调水方案, 而应基 于重塑市民与环境的关系, 采取更为自主 的能够满足当地用水需求的水策略。LAF

注释

了解更多作者研究成果, 请访问www.thomasnideroest.com.
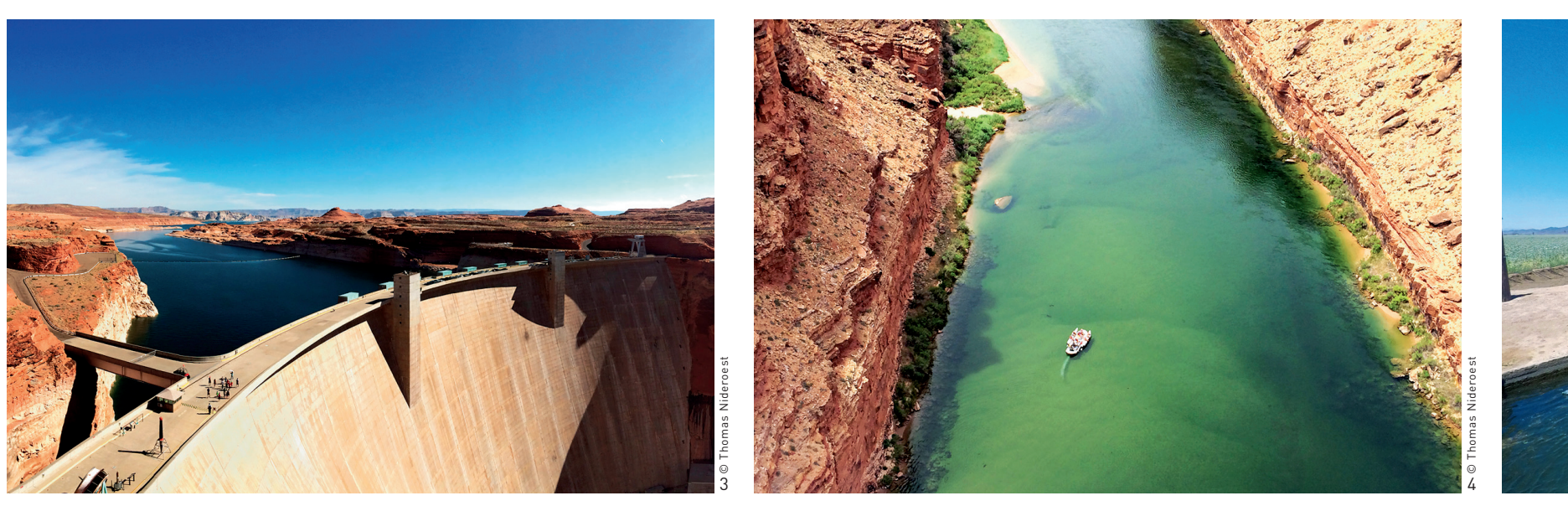

吉市的葛兰峡谷大坝和 水库

4. 在位于亚利桑那州马布 尔峡谷的科罗拉多河进 行考察

. 位于亚利桑那州莫哈维 流域的农业用水分配意

6. 位于加利福尼亚州穿圣 贝纳迪诺县而过的科罗 拉多河引水渠

位于加利福尼亚州洛杉 矶市的恩西诺水库
3. View of Glen Canyon Dam and reservoir at Page, Arizona.

4. A Colorado River expedition at Marble Canyon, Arizona.

5. Agricultural water distribution pump in the Mohave Valley, Arizona.

6. Colorado River Aqueduct crossing the San Bernardino County. California

7. View of the Encino Water Reservoir, Los Angles, California.

\section{Effects of Drought - An International Survey}

On November 12th, 2017, the South African newspaper The Times reported about Cape Town's dwindling water resources and their daunting quest for alternative water supply ${ }^{[1]}$. Just one month later, Live Science publishes an article titled “Day Zero: Cape Town Could Become 1st Major City to Run

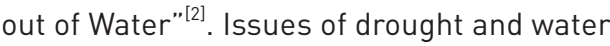
shortages during extreme events, such as the 2010 China drought and dust storms, or the 2011 2017 historic droughts in California, effect arid regions globally. It is the interplay of changing environmental and demographic processes in a rapidly growing economy, altering the demand over available water resources. Arid regions around the world comprise approximately 41 percent of the global surface area ${ }^{[3]}$. These drylands are inhabited by $1 / 3$ of the global population, are home to several megacities and nurture a multibillion-dollar economy ${ }^{[3]}$ from their mineral rich grounds and fertile soils. In these geographies, precipitation cycles depend on an exchange of climatic systems. They define the hydrological cycle, shape the water bodies, and replenish the local fresh water resources. Well known, the El Niño and la Niña cycles ${ }^{[4]}$ influence both temperatures and rainfalls on a global scale. In recent years, shifting patterns delayed or relocated these rainfalls ${ }^{[4]}$, effecting the availability of fresh water, which pose a challenge for both nature and human kind.

"When the only water left is gray," is the title to a design research project under the Harvard based Charles Eliot Traveling Fellowship. This survey studies the effects of drought in arid regions on six international case studies (Fig. 1). By documenting their territorial water system (Fig. 2), in connection to the socio-economic and socio-ecological effects of megaprojects, the survey reveals issues of water scarcity. This article introduces the study project and discusses the current water discourse from the perspective of landscape architecture. Hereby, the emphasis lays on revealing the perspectives of a global issue through the means of design research. It frames a plurality of local interventions under a landscape-based planning and design approach.

\section{Megaprojects and the Crisis of Nature}

\subsection{The New Deal Era - A Paradigm of Scarcity}

Rapid urban growth at the turn of the 20th century, forced Los Angeles to extend their water supply system into the Owens Valley ${ }^{[5]}$. Chief Engineer and visionary William Mulholland of the Los
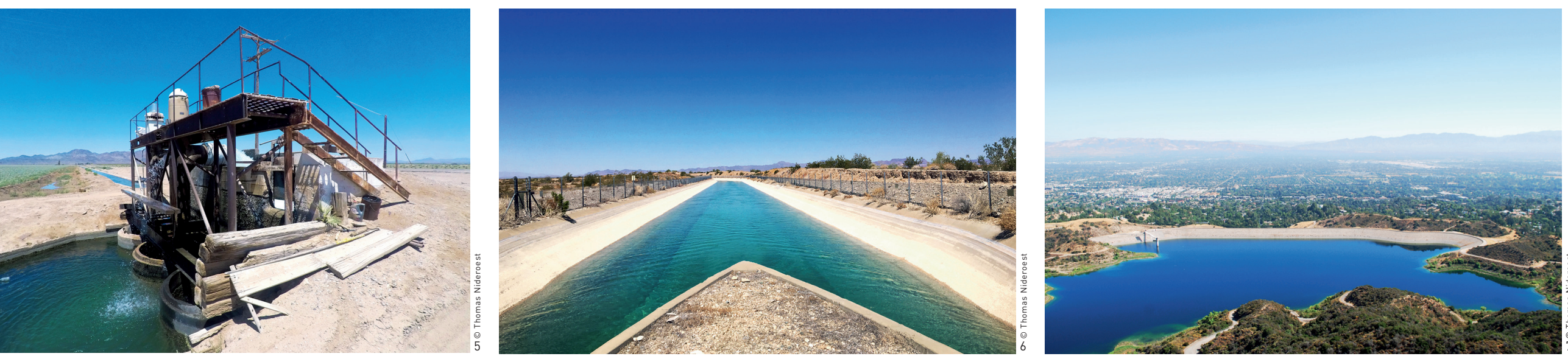
Angeles Department of Water and Power proposed the construction of the first L.A. Aqueduct $^{[6]}$. To get the project approved, Mulholland capitalized on the ongoing drought, which had already manifested in the fear of citizens ${ }^{[7]}$. Anticipating a rapidly growing metropolis, Mulholland laid eyes on the Colorado. The 1922 Colorado River Compact regulated the allocation of the river's water between the seven bordering states $^{[8]}$. This agreement came just in time, as the U.S. was about to experience another severe crisis. During the 1930s, the Dust Bowl in the Mid-West and the Great Depression, resulted in the commission of Hoover Dam ${ }^{[9]}$. This engineered masterpiece set a new standard and established

California as a water frontier. Thereafter, using the crisis of nature as an economic trajectory depicted a reactional behavior. After the institutionalization and division of the Colorado River into an Upper and Lower basin, California was the first state to put in a request for water ${ }^{[10]}$. Several megaprojects, including the Colorado River Aqueduct (389 km), the All-American Canal (130 km), or the San Diego Aqueduct (362 km), had to be built to convey this water. Following the Colorado River, Figures $3 \sim 7$ provide an impression of the territorial water system, marginalizing the native landscape between the Glen Canyon Dam in Arizona, and the Morelos Dam near Mexican border.

\subsection{Water Commodification at a Global Scale}

Continuous economic and population growth, in areas with limited water resources, come in desperate need for alternative water supply. To stabilize the local economy and facilitate continuous population growth, governments around the world adopted California's practices to store and convey water by extending their waterenergy-network into foreign watersheds. This understanding of water as a stock ${ }^{[11]}$ created a systematic dependency on resources far beyond the jurisdictional- and national borders, which means that water flows from a specific resource into one or multiple economic subsystems, where it is consumed ${ }^{[11]}$. After its consumption and qualitative appropriation, the water is released into our sinks as effluents and pollutants $^{[12]}$. The consequences of this urbanization process are manifold and shall be explored on three case studies.

\subsubsection{North China Plain - The South-North-}

Water-Transfer

Beijing, located in the North China Plain, was featured with abundant streams and fresh water resources ${ }^{[13]}$. This second largest plain was formed by deposits of the Yellow River, the Huai and the Hai River ${ }^{[14]}$. Shifting and declining precipitation cycles, severe droughts, reoccurring floods, as well as a rapidly growing economy and urban expansion, outgrew the local resources. The results were depleting aquifers from over-extraction, declining water quality due to poorly regulated industries, and an encroaching desertification on fertile land ${ }^{[13]}$.

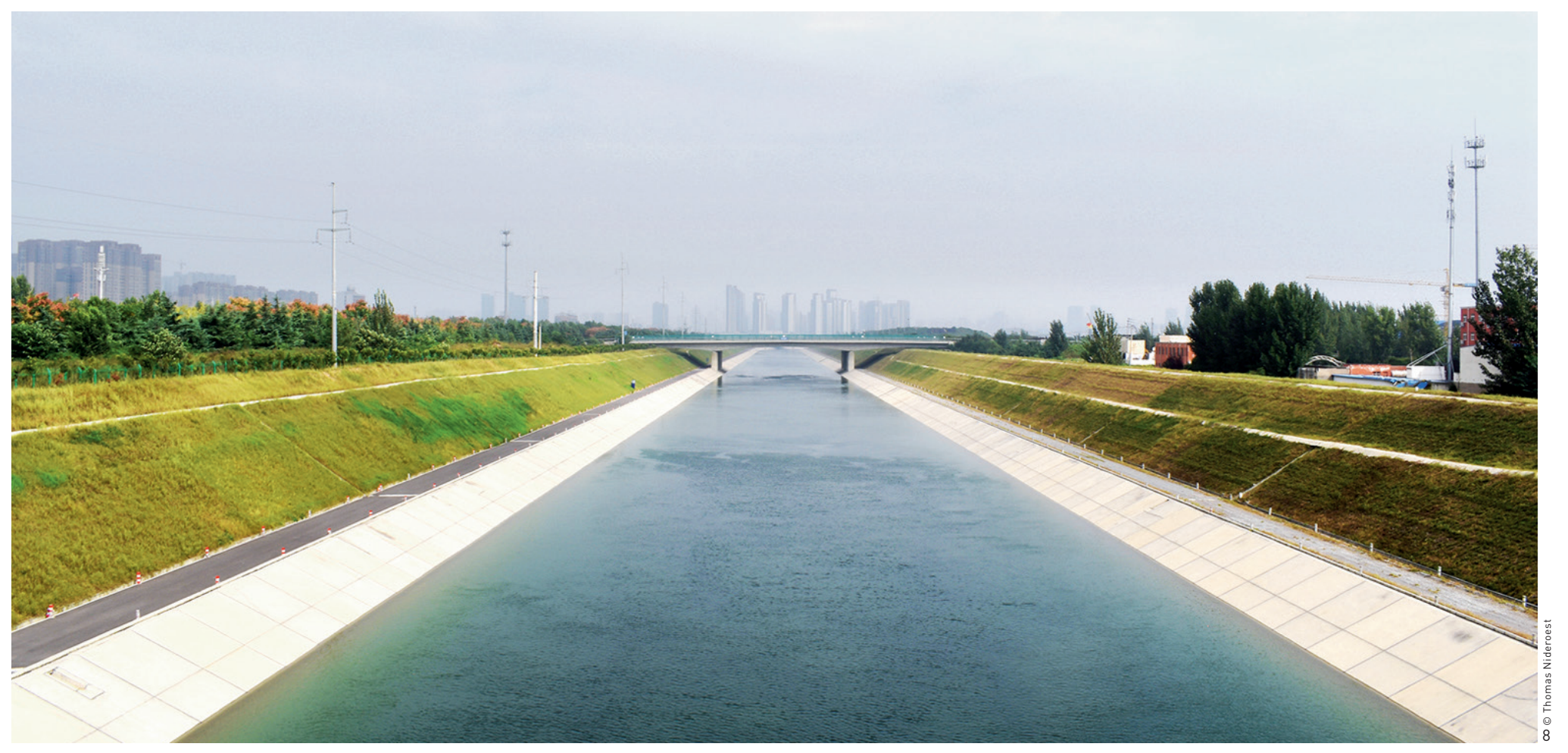



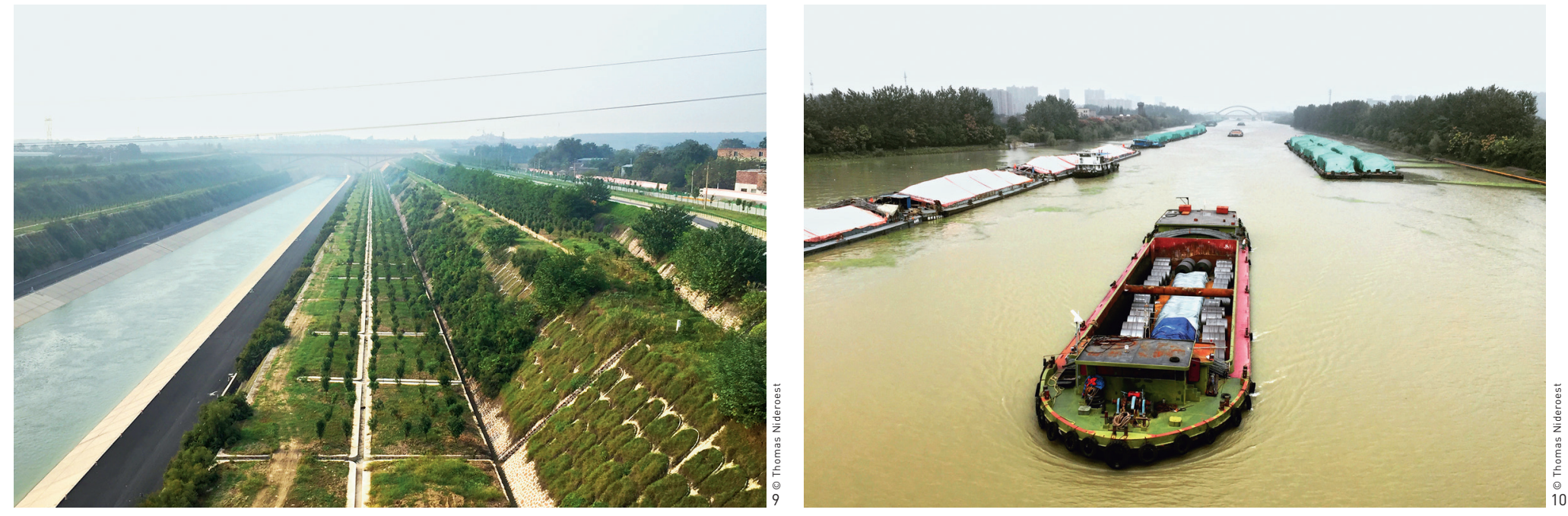

In 1952, Chairman Zedong Mao addressed the water shortages with the idea to borrow water from the abundant South ${ }^{[15]}$. His vision took form in the largest water infrastructure, the South-North-Water-Transfer (SNWT) project with 2,400 km network of canals and tunnels. The aqueduct consists of the three main routes: East, Central and West. They divert water from the Yangtze River Basin by linking the Yangtze, Huai, Hai and Yellow Rivers (si-heng san-zong) (Fig. 8 $10)^{[13]}$. Despite environmental inequalities, the North China Plain continues to grow. Recently, the Central Government plans the construction of Xiong-An New Area, a multimillion city at the southern periphery of Beijing and Tianjin ${ }^{[16]}$. The new special economic zone is supposed to offset Beijing's urban expansion ${ }^{[16]}$ yet increases the overall water demand. In this context, megaprojects such as the SNWT appear to be "an engineering solution to an ecological discrepancy" ${ }^{[17]}$.

\subsubsection{South Africa - Day Zero}

Cape Town faces the most profound water crisis in history. Severe water shortages with a projected Day Zero on April 22, $2018^{[18]}$ are the results of legislative entitlements, a lack of institutional responsibilities, and a misfit between political and technical actors within the council ${ }^{[19]}$. Climatic changes responsible for decreasing annual rainfalls, evaporation of reservoirs due to high temperatures, and a continuous influx of people further add to the equation (Fig. 11, 12). The Water Act of 1998 as part of the post-apartheid legislation, entitles citizens with sufficient water supply ${ }^{[20]}$. Hereby, the National Government is accountable to protect, develop, conserve, manage and control water resources ${ }^{[18]}$. Whereas the provincial- and municipal government are responsible for the local management, maintenance and delivery of water $^{[19]}$. The city of Cape Town, however, is not entitled to invest in infrastructures producing water for their overall supply. Furthermore, the 1969 National Water Guidelines is outdated and contradicting the current crisis in terms of water quality standards, which complicates local water management and discourages change.

2.2.3 Singapore - Water to Become the Nation's Single Most Threat

Located on tropical islands in South-East Asia, Singapore gained its independence from the UK in $1963^{[21]}$ and managed to uphold a former water agreement after splitting off from Malaysia in $1965^{[22]}$. However, imported water from Johor started to decline in quality and quantity, as Malaysia experienced several droughts $^{[22]}$. Political pressure and the termination of this long-term water supply agreement by 2061 forced Singapore to change its course ${ }^{[23]}$. To become water independent, Singapore's first Prime Minister, Kuan Yew Lee, declared water as the top priority in government policies and urban development ${ }^{[22]}$.

\section{Landscape, an Approach towards Abundance?}

Water is a crucial requirement for both social and economic lagriculture and industries) growth processes. Restrictions and limitations of water availability confines the production of products and creation of jobs, which is connected to urban growth. The previous chapters argue that water scarcity was produced with the commodification of water under the New Deal Era. This water scheme requires continuous access to foreign 


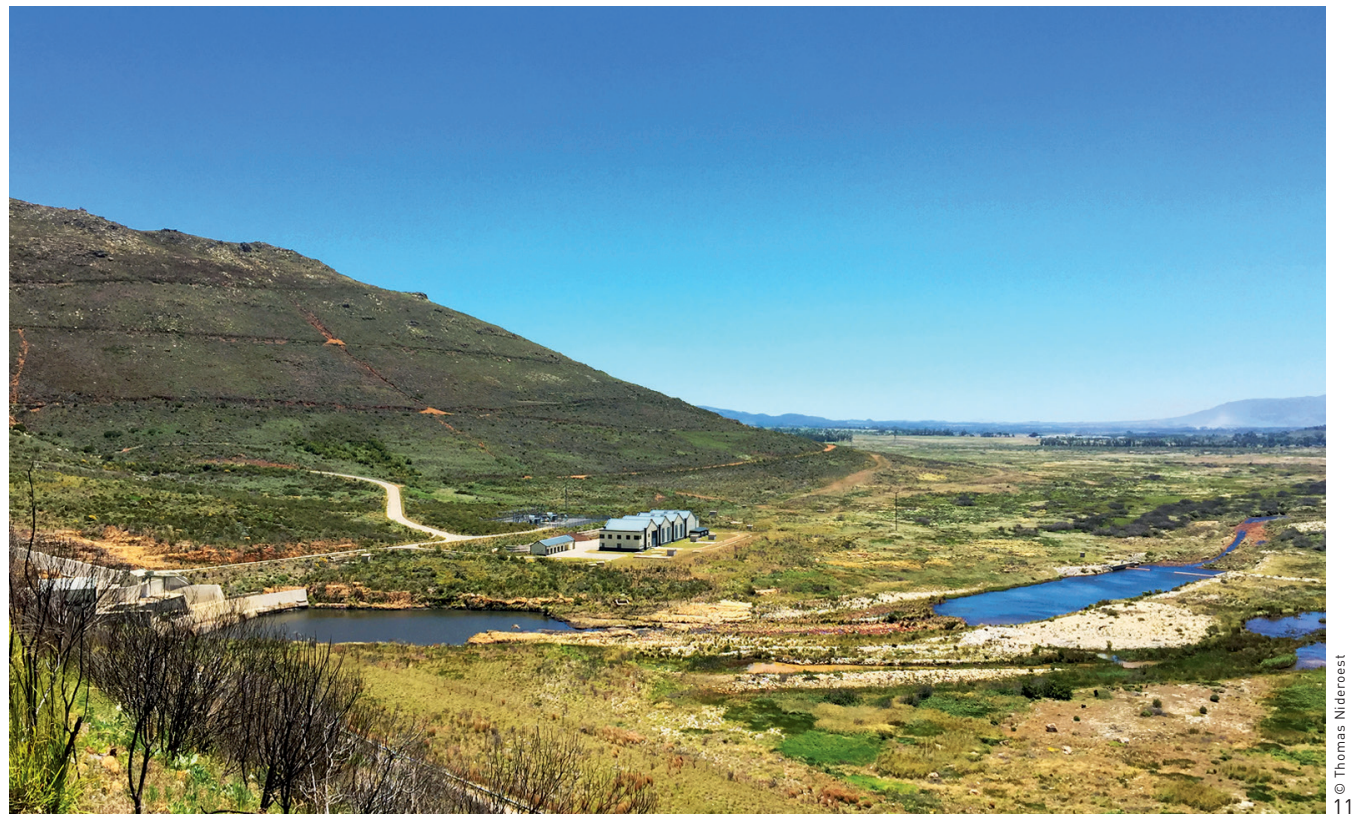

watersheds, extending the water-energynetwork from the place of production to the place of consumption. Hereby, centralized water systems produce a territorial gap ${ }^{[24]}$, a social disconnect that affects the natural environment and its ability to regenerate. While inter-basin-water-transfer projects can bridge the water shortage and sustain the economic subsystem, how far can this
As the North China Plain continues to grow, it needs to adapt to a new mindset of planning and decision making across all jurisdictions. Hereby, developing smart land use regulations with a strong implied landscape framework could capitalize on the natural water bodies and wetlands in both urban and rural areas. For example, the "sponge city" strategy helps to increase the urban resilience during flood events, protect and enhance the water quality in streams, lakes and aquifers, and create a socio-ecological connection between citizens and their environment. Therefore, the rapidly growing "Chinese Suburb" can be organized as a larger community that becomes a net producer of fresh water. By recycling and recirculating their gray water, the community closes the hydrological cycle and acknowledges water as a renewable resource. The Berg River Restoration Project in the Western Cape addresses water quality by managing waste and wastewater flows ${ }^{[26]}$. Communities of lower income along the river are being educated through the implementation of pilot projects ${ }^{[26]}$. This interaction establishes the community as a main shareholder, creates an

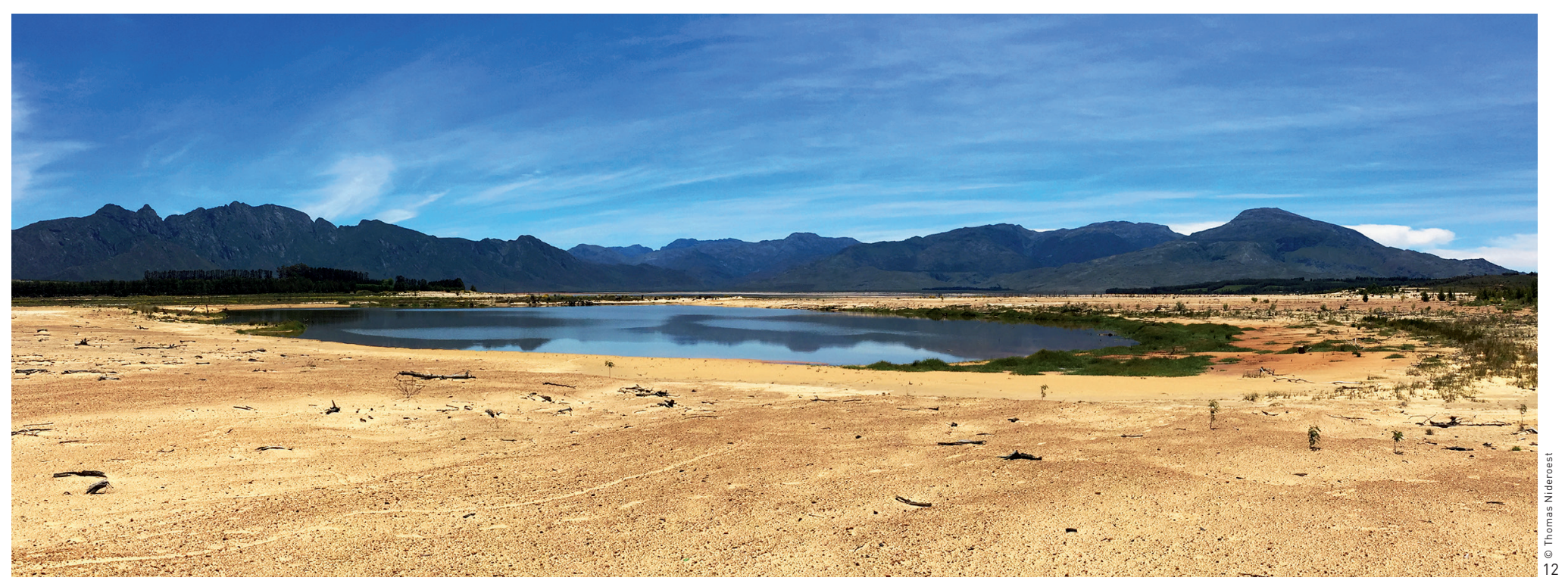



格河水坝泄洪区

12. 低水位时期的希沃特思 路夫水坝

13. 位于新加坡的滨海堤坝 将海水与淡水分隔开来

11. View of the Berg River Dam outflow, Western Cape.

12. Low water levels at Theewaterskloof Dam

13. The Marina Barrage disconnecting sea from resh water, Singapore. understanding of self-reliance and ownership. Singapore established a fourtap strategy ${ }^{[27]}$ to become a net producer of water. This approach capitalizes, besides imports from Malaysia, on the catchment of water through the extension of their storage capacity. In addition, each tap is tied to a landscape-based approach, reconnecting both citizens and visitors to their native landscape, as The Marina Barrage (Fig. 13) and Bishan-Ang Mo Kia Park demonstrate.

The discussed projects and notions, address issues of water scarcity locally. The landscape-based planning and design approach mentioned enhances the socio-economic and socio-ecological processes. Hereby, landscape is recognized as a medium beyond its disciplinary implications. It is understood as a paradigm and method, addressing critical challenges from the territory to the community. This proposition, if taken seriously, will have a changing effect on our cities. It addresses not only supply, but also the demand of water by reconnecting citizens to their environment. LAF

NOTE

For more information about the author's research, please visit www.thomasnideroest.com.

\section{REFERENCES}

[1] Jordan, B. (2017, November 12). Cape of evaporating hope hunts water solutions. Sunday Times. Retrieved from https://www.timeslive.co.za/sunday-times/news/2017-1111-cape-of-evaporating--hope-hunts--water-solutions/

[2] Gannon, M. (2018, January 18). Day Zero: Cape Town Could Become 1st Major City To Run Out of Water. Planet Earth. Retrieved from https://www.livescience.com/61471-capetown-running-out-of-water.htm

[3] Food and Agriculture Organization of the United Nations and Earthscan. (2008). Drylands, people and land use. In P. Koohafkan \& B. Stewart (Eds.), Water and Cereals in Drylands (pp. 5-16). London: Routledge.

[4] Landman, W. A. (2017). Personal Interview on Cape Town Weather. Faculty of Natural and Agricultural Sciences, University of Pretoria.

[5] Reisner, M. (1993). Cadillac Desert: The American West and Its Disappearing Water. New York: Penguin Books.

[6] Kahrl, L.W. (1983). Water and Power: The Conflict over Los Angeles' Water Supply in the Owens Valley. Berkeley: University of California Press.

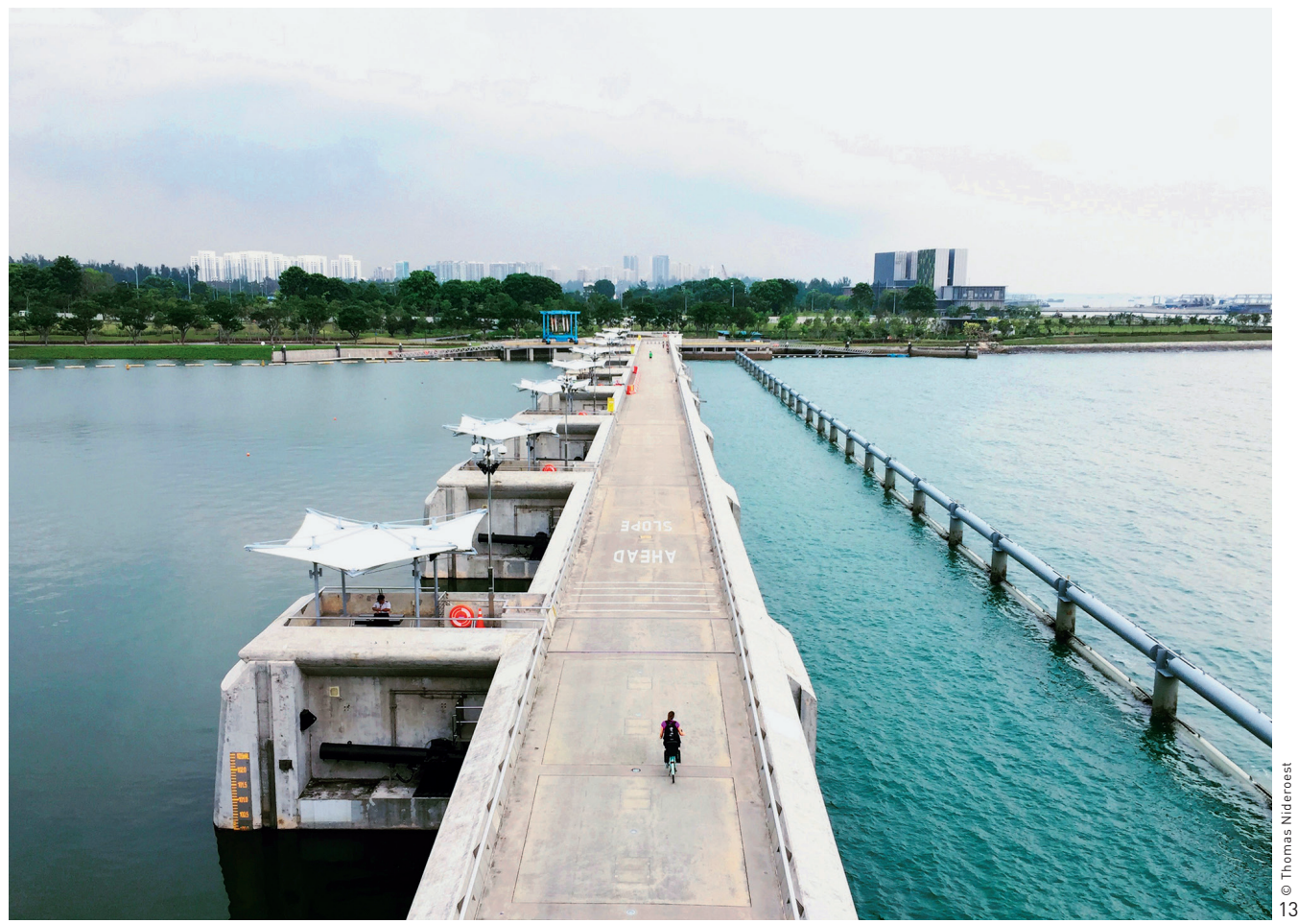

(7] Kinsey, D. (1930). Thirst - Promoting the Aqueduct. Los Angeles: California Metropolitan Water District. Available from https://www.youtube.com/ watch?v=C5H219p99HA\&t=31s

[8] Hundley, N. (2009). Water and the West: the Colorado River Compact and the politics of water in the American WestBerkeley: University of California Press.

[9] Dunar, A. J., \& McBride, D. (2001). Building Hoover Dam: An Oral History of the Great Depression. Reno, Nevada: University of Nevada Press.

[10] Bureau of Reclamantion. (2008). The Law of the River. Los Angeles: U.S. Deparment of the Interior. Retrieved from http://www.usbr.gov/lc/region/g1000/lawofryr.html

[11] Turton, A. (2012, March). A South African Perspective on Climate Change, Food Security and Water. In 4th BRICS Academic Forum (pp. 1-36). New Delhi: BRICS Academic Forum

[12] Meadows, D. H., \& Randers, J. (2004). Limits to Growth, The 30-Year Update. White River Junction: Chelsea Green Publishing Company.

[13] Magee, D. (2011). Moving the River? China's South-North Water Transfer Project. In S. D. Brunn (Ed.), Engineering Earth: The Impacts of Megaengineering Projects (pp. 1499 1514). Dordrecht: Springer

[14] Ghassemi, F., \& White, I. (2012). Inter-Basin Water Transfer: Case Studies from Australia, United States, Canada, China and India. Cambridge: Cambridge University Press.

[15] Kuo, L. (2014, March). China has Launched the Largest Water Pipeline Project in History. The Atlantic. Retrieved from https://www.theatlantic.com/international/archive/2014/03/ china-has-launched-the-largest-water-pipeline-project-inhistory/284300/

[16] Yang, X. L. (2017). Personal Interview on the SNWT Project. Asia-Pacific Centre for Water Security, Tsinghua University

[17] Larson, C. (2014, December). World's Largest River Diversion Project Now Pipes Water to Beijing. Bloomberg Businessweek. Retrieved from https://www.bloomberg.com/ news/articles/2014-12-15/world-s-largest-river-diversionproject-now-pipes-water-to-beijing
[18] Payne, S. (2018, January). What national government is doing about Cape Town's water ciris. Ground Up. Retrieved from https://www.groundup.org.za/article/dam-project-speededtackle-cape-town-water-crisis/

[19] Tamsin, F. (2017). Personal Interview on Cape Town Water Water-New Build Workstream Lead, City of Cape Town.

[20] Saleth, M. R. (2006). Understanding Water Institutions: Structure, Environment and Change Process. In S. Perret, S. Farolfi \& R. Hassan (Eds.J, Water Governance for Sustainable Development (pp. 3-20). London: Earthscan.

[21] Tortajada, C., Joshi, Y. K., \& Biswas, A. K. (2013). The Singapore Water Story: Sustaninable Development in an Urban City-State. London and New York: Routlege, Taylor \& Francis Group.

[22] Public Utilities Board. Singapore's National Water Agency. (2016). Singapore Water Story. Retrieved from https://www. pub.gov.sg/watersupply/singaporewaterstory

[23] Soon, T. Y., Jean, L. T., \& Tan , K. (2008). Clean, Green and Blue: Singapore's Journey towards Environmental and Water Sustainability. Singapore: Institute of Southeast Asian Studies.

[24] Agnew, J. (1994). The erritorial trap: the geographical assumptions of international relations theory. Review of International Political Economy, 1(1), 53-80.

[25] Gleick, P. H., \& Palaniappan, M. (2010). Peak water limits to freshwater withdrawal and use. Proceedings of the Nationa Academy of Sciences of the United States of America, 107(25), $11155-11162$

[26] Mingo, J. (2017). Personal Interview on Berg River Restoration Project. Department of Environmental Affairs and Development Planning, Western Cape. Retrieved rom https:/wwi Plasing, Westicacom Cape. Retrieved interview-with-jeson-mingo-berg-river-tosk-manawestern-cape-departmen
development-plannin

[27] Public Utilities Board. (2016). Our Water Our Future. Singapore: Singapore's National Water Agency. Retrieved from https://www.pub.gov.sg/Documents/ PUBOurWaterOurFuture.pd 